\title{
Increased epidermal growth factor in experimental diabetes related kidney growth in rats
}

\author{
R .E . G ilbert ${ }^{1}$, A . Cox ${ }^{1}$, P. G. M cN ally², L. L. Wu1 ${ }^{1}$, M . D ziadek ${ }^{3}$, M . E . Cooper ${ }^{1}$, G . Jerums ${ }^{2}$ \\ ${ }^{1}$ Department of Medicine, Austin and Repatriation Medical Centre, University of Melbourne, Victoria, Australia \\ ${ }^{2}$ Endocrinology Unit, Austin and Repatriation Medical Centre, University of Melbourne, Victoria, Australia \\ ${ }^{3}$ Department of Anatomy, University of Melbourne, Victoria, Australia
}

Summary Renal enlargement is a characteristic feature of human and experimental diabetes mellitus that may be predictive of subsequent nephropathy. In the streptozotocin diabetic rat kidney growth rapidly follows the induction of experimental diabetes but the mechanisms responsible for this growth are poorly understood. Epidermal growth factor (EGF) is a potent mitogen for renal tubular cells. Thirty one male Sprague-Dawley rats aged 13 weeks were randomised to receive either streptozotocin (diabetic, $\mathrm{n}=20$ ) or buffer (control, $\mathrm{n}=11$ ). Animals were studied on days $1,3,5$ and 7 following streptozotocin. Diabetes was associated with a 3-fold increase in urinary EGF excretion $(223 \pm 15$ vs $59 \pm 5 \mathrm{ng} /$ day, mean \pm SEM, diabetic vs control, $p<0.0001)$ and 3 6 fold increase in renal EGF mRNA relative to controls $(p<0.001)$. A transient rise in kidney EGF protein was noted on day 1 . There was no difference between diabetic and control animals with regard to intrarenal sites of EGF expression or in plasma EGF. These data suggest that the increased urinary EGF excretion in diabetic animals is the result of enhanced local production and that EGF is not stored for a prolonged period within renal tubular cells but is released following its synthesis. In the context of the known intrarenal actions of EGF this growth factor may play a role in the pathogenesis of diabetes related kidney growth. [Diabetologia (1997) 40: 778785]

Keywords Diabetes mellitus, epidermal growth factor, kidney growth, mRNA.
Renal enlargement is a characteristic feature of human [1] and experimental diabetes mellitus [2]. In humans, renal enlargement may be predictive of subsequent nephropathy in patients with insulin-dependent [3] and non-insulin-dependent diabetes [4].

In the streptozotocin (STZ) rat model, increased kidney weight is detectable $36 \mathrm{~h}$ following the induction of diabetes and increases by approximately

Received: 16 December 1996 and in revised form: 4 March 1997

Corresponding author: Dr. R.E. Gilbert, Endocrinology Unit Austin and Repatriation Medical Centre (Austin Campus), Studley Road, Heidelberg, Victoria, 3084, Australia

A bbreviations: EGF, Epidermal growth factor; rRNA, ribosomal ribonucleic acid; STZ, streptozotocin; TGF- $\beta$, transforming growth factor- $\beta$; PDGF, platelet-derived growth factor; OD, optical density; AU, arbitrary units; ROD, relative optical density; DCT, distal convoluted tubule; TAL, thick ascending loop of Henle.
$20 \%$ within 1 week [5]. The mechanisms responsible for this growth are poorly understood.

The mammalian kidney is a major site of synthesis of epidermal growth factor (EGF) [6]. EGF is thought to act in a paracrine, autocrine or juxtacrine manner [7] and not as a circulating hormone given its low plasma concentration [8]. In addition to its ability to promote cell growth and proliferation, EGF exerts a variety of effects on renal function [9].

Previous studies have demonstrated an increase in kidney EGF in the compensatory renal hypertrophy that follows uninephrectomy $[10,11]$. An increase in urinary EGF has been demonstrated in early experimental diabetes [12] in the absence of a change in kidney EGF. Only one study has examined EGF gene expression in experimental diabetes and found no change in glomerular EGF mRNA [13]. Thus the site of origin of the augmented urinary EGF excretion in diabetes is not known although there is some 
dispute regarding a possible glomerular source of EGF expression $[9,13]$.

The aim of the present study was to assess whether EGF gene transcription is altered in diabetes and to localise the sites of such change within the kidney.

\section{Materials and methods}

A nimals. Thirty one male Sprague-Dawley rats aged 13 weeks were randomised to control and diabetic groups. Diabetes was induced in 20 rats by the intravenous administration of STZ $50 \mathrm{mg} / \mathrm{kg}$ body weight. The remaining 11 rats were injected with citrate buffer and served as controls. Diabetic rats were killed at $1(n=4), 3(n=4), 5(n=4)$ and 7 days $(n=7)$ following injection of STZ. All control animals were killed at 7 days following injection of vehicle. At each time point diabetic and control rats were used to study EGF gene expression and peptide content. Prior to decapitation animals were weighed, the kidneys were then excised, decapsulated and weighed. Kidneys were then snap frozen in liquid nitrogen and stored at $-80^{\circ} \mathrm{C}$ for later measurement of EGF mRNA (left kidney) and peptide content (right kidney). Blood, obtained at decapitation was collected in lithium heparin tubes, placed on ice, spun immediately, separated and stored at $-20^{\circ} \mathrm{C}$. Plasma glucose at killing was measured by a glucose oxidase technique [14]. In addition, 4 diabetic and 4 control rats were housed in metabolic cages in order to obtain daily urine collections. At 7 days these animals were killed and kidneys were fixed in $10 \%$ neutral buffered formalin for in situ hybridisation studies (left kidney) and paraformaldehyde for immunohistochemistry (right kidney). All aspects of the experiment were approved by the animal ethics committee of the Austin and Repatriation Medical Centre.

RN A preparation and analysis. Tissues were homogenised (Ultra-Turrax; Janke and Kunel, Staufen, Germany) and total RNA was isolated by the acid guanidinium thiocyanate-phenol-chloroform extraction method [15]. RNA purity and concentration were determined spectrophotometrically. Twenty microgram samples were denatured and electrophoresed through $0.8 \%$ agarose formaldehyde gels. RNA integrity was verified by examination of the $28 \mathrm{~S}$ and $18 \mathrm{~S}$ ribosomal bands of ethidium bromide stained material under ultraviolet light. RNA was then transferred onto nylon filters (Hybond-N; Amersham, Amersham, UK) by capillary action and fixed by ultraviolet irradiation. Filters were probed with a 400 base pair Eco RI/Hind III cDNA coding for murine EGF (gift of Dr. P. Fuller, Monash Medical Centre, Clayton, Australia) previously used in studies of rat kidney [16] reflecting the high degree of sequence homology between rat and mouse EGF mRNA [17]. The probe was labelled with $\left[\alpha^{-32} \mathrm{P}\right] \mathrm{dCTP}$ by random primed DNA synthesis (Boehringer Mannheim, Mannheim, Germany). Hybridisation was performed at $42{ }^{\circ} \mathrm{C}$ for $24 \mathrm{~h}$ in $50 \%$ formamide, $45 \mathrm{mmol} / 1 \mathrm{Na}_{2} \mathrm{HPO}_{4}, 5 \times$ Denhardt's solution, $0.5 \%$ SDS and sonicated salmon sperm DNA. Filters were then washed in solutions of decreasing ionic strength and increasing temperature. The final stringency was $0.1 \times$ standard saline citrate, $0.1 \% \mathrm{SDS}$ for $20 \mathrm{~min}$ at $42^{\circ} \mathrm{C}$. Filters were then exposed to X-ray film (Kodak X-Omat; Eastman-Kodak, Rochester, N.Y., USA) at $-80^{\circ} \mathrm{C}$ for $1-5$ days. The relative intensity of autoradiograms was determined by scanning densitometry (LKB Ultroscan XL; Bromma, Sweden). All results were corrected for differences in RNA loading by rehybridisation with an oligonucleotide probe for $18 \mathrm{~S}$
rRNA end labelled with $\left[\alpha^{-32} \mathrm{P}\right] \mathrm{dCTP}$ by terminal transferase (Boehringer Mannheim).

In situ hybridisation. An anti-sense riboprobe was generated as previously described. In brief, the cDNA coding for EGF used in Northern analysis was cloned into pGEM 3Z (Promega, Maddison, Wis., USA) and linearized with Hind III. An antisense riboprobe was then generated using T7 RNA polymerase. Purified riboprobe length was adjusted to approximately 150 bases by alkaline hydrolysis. Four micrometer thick sections were cut onto slides precoated with 3-aminopropyltriethoxysilane and baked overnight at $37^{\circ} \mathrm{C}$. Tissue sections were dewaxed and rehydrated in graded ethanol and milliQ water, equilibrated in $\mathrm{P}$ buffer (50 mmol/l Tris-HCl, pH 7.5, $5 \mathrm{mmol} / \mathrm{l} \mathrm{EDTA})$ and incubated in $125 \mathrm{\mu g} / \mathrm{ml}$ Pronase E in P buffer for $10 \mathrm{~min}$ at $37^{\circ} \mathrm{C}$. Sections were then washed in $0.1 \mathrm{~mol} / \mathrm{l}$ sodium phosphate buffer, $\mathrm{pH} 7.2$, rinsed in milliQ water, dehydrated in $70 \%$ ethanol and air dried. Hybridisation buffer containing $2 \times 10^{4} \mathrm{cpm} / \mu \mathrm{l}$ riboprobe in $300 \mathrm{mmol} / 1 \mathrm{NaCl}, 10 \mathrm{mmol} / \mathrm{l}$ Tris- $\mathrm{HCl}, \mathrm{pH} 7.5$, $10 \mathrm{mmol} / 1 \mathrm{Na}_{2} \mathrm{HPO}_{4}, 5 \mathrm{mmol} / \mathrm{l}$ EDTA, $\mathrm{pH}$ 8.0, $1 \times$ Denhardt's solution, $50 \%$ formamide, $17 \mathrm{mg} / \mathrm{ml}$ yeast RNA, $10 \%$ weight/ volume dextran sulfate, was heated to $85^{\circ} \mathrm{C}$ for $5 \mathrm{~min}$. Twentyfive $\mu l$ of this solution was then added to each section. Hybridisation was performed overnight at $60^{\circ} \mathrm{C}$ in $50 \%$ formamide humidified chambers. As controls for non-specific signal sections were incubated with sense riboprobe or treated with RNAse prior to hybridisation. Slides were washed in $2 \times$ SSC containing $50 \%$ formamide prewarmed to $50^{\circ} \mathrm{C}$ to remove coverslips. Sections were then washed in the above solution for 1 hour at $55^{\circ} \mathrm{C}$, rinsed 3 more times in RNAse buffer $(10 \mathrm{mmol} / \mathrm{l}$ Tris$\mathrm{HCl}, \mathrm{pH} 7.5,1 \mathrm{mmol} / \mathrm{l} \mathrm{EDTA}, \mathrm{pH} 8.0,0.5 \mathrm{~mol} / \mathrm{l} \mathrm{NaCl})$ and then incubated with RNAse A $(150 \mu \mathrm{g} / \mathrm{ml})$ for $1 \mathrm{~h}$ at $37^{\circ} \mathrm{C}$. Sections were later washed in $2 \times \mathrm{SSC}$ for $45 \mathrm{~min}$ at $55^{\circ} \mathrm{C}$, dehydrated in graded ethanol, air dried and exposed to Kodak X-Omat autoradiographic film for 3 days. Slides were then dipped in Ilford K5 nuclear emulsion (Ilford, Mobberley, Cheshire, UK), stored in a light-free box with desiccant at $4^{\circ} \mathrm{C}$ for 21 days, immersed in Kodak D19 developer, fixed in Ilford Hypam and stained with haematoxylin and eosin.

Quantitative autoradiography. The relative distribution of EGF gene expression within individual kidneys was quantified by comparing EGF mRNA in the cortex with that in the outer medulla. These regions were selected to reflect the anatomical distribution of the major sites of EGF expression: the distal convoluted tubule (DCT) and thick ascending limb of the loop of Henle (TAL) with the former located in the cortex and the latter found predominantly in the outer medulla [19]. Densitometry of autoradiographic images obtained by in situ hybridization was performed by computer-assisted image analysis as described by Baskin and Stahl [20] using the MCID system (Image Research, Ontario, Canada). In brief, in situ autoradiographic images were placed on a uniformly illuminating fluorescent light box (Northern Light Precision Luminator Model C60; Image Research, Ontario, Canada) and captured using a video camera (Sony Video Camera Module CCD, Tokyo, Japan) connected to an IBM AT computer with a $512 \times 512$ pixel array imaging board with 256 gray levels. Following appropriate calibration by constructing a calibration curve of optical density versus radioactivity [21, 22] quantitation of digitalized autoradiographic images was performed with the MCID software and expressed as relative optical density (ROD). Cortex:outer medulla ROD was analysed in control and day 7 diabetic animals.

E GF peptide. Renal homogenates were prepared in $2.5 \mathrm{ml}$ of ice cold normal saline using a glass and teflon homogeniser. 
Table 1. Body and kidney weight, plasma and kidney EGF in experimental animals

\begin{tabular}{|c|c|c|c|c|c|}
\hline & \multirow[t]{2}{*}{ Control } & \multicolumn{4}{|l|}{ Diabetes } \\
\hline & & Day 1 & Day 3 & Day 5 & Day 7 \\
\hline $\mathrm{n}$ & 11 & 4 & 4 & 4 & 7 \\
\hline Rat weight (g) & $373 \pm 9$ & $364 \pm 18$ & $352 \pm 11$ & $299 \pm 20^{\mathrm{b}}$ & $311 \pm 17^{\mathrm{b}}$ \\
\hline Left kidney weight (g) & $1.1 \pm 0.4$ & $1.1 \pm 0.6$ & $1.2 \pm 0.2$ & $1.3 \pm 0.4^{b}$ & $1.3 \pm 0.1^{\mathrm{b}}$ \\
\hline Renal EGF ng/g & $7.3 \pm 0.7$ & $11.7 \pm 1.5^{\mathrm{a}}$ & $8.6 \pm 1.2$ & $5.7 \pm 0.3$ & $8.2 \pm 1.0$ \\
\hline Plasma EGF ng/ml & $1.6 \pm 0.3$ & $1.7 \pm 0.1$ & $1.6 \pm 0.1$ & $1.5 \pm 0.2$ & $1.7 \pm 0.2$ \\
\hline
\end{tabular}

Results are expressed as mean \pm SEM. ${ }^{\mathrm{a}} \mathrm{p}<0.05,{ }^{\mathrm{b}} \mathrm{p}<0.01,{ }^{\mathrm{c}} \mathrm{p}<0.001$

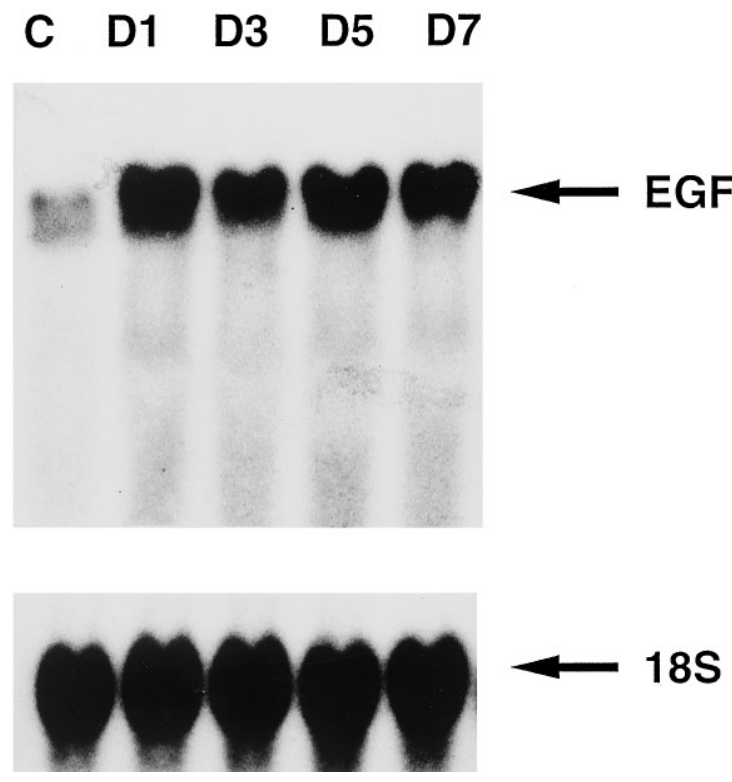

Fig. 1. Expression of kidney EGF mRNA following induction of STZ diabetes. Representative Northern blot of EGF in control (C) and rats studied at 1, 3, 5 and 7 days (D1, D3, D5 and D7) duration of diabetes. Expression of $18 \mathrm{~S}$ rRNA is also shown

Samples were centrifuged at $10000 \mathrm{~g}$ for $20 \mathrm{~min}$ at $4^{\circ} \mathrm{C}$. The supernatant was decanted and stored at $-20^{\circ} \mathrm{C}$ for later assay of EGF. Urine, plasma and renal homogenate were assayed for EGF by radioimmunoassay using a kit for mouse EGF and a rat EGF standard (Amersham). The sensitivity of the assay was $4 \mathrm{ng} / \mu \mathrm{l}$ and the intra-assay coefficient of variation was $6.5 \%$.

EG F immunohistochemistry. Five $\mu \mathrm{m}$ sections were rehydrated and treated with $1 \% \mathrm{H}_{2} \mathrm{O}_{2}$ /methanol followed by incubation in Protein Blocking Agent (Lipshaw-Immunon, Pittsburgh, Penn., USA) for $20 \mathrm{~min}$ at room temperature. Sections were then incubated with anti-EGF antibody (Serotec, Oxford, UK) for $30 \mathrm{~min}$ at room temperature, washed in phosphate buffered saline and incubated with biotinylated goat anti-rabbit immunoglobulin (DAKO, Carpinteria, Calif., USA) and peroxidase-conjugated strepavidin (DAKO). Peroxidase conjugates were subsequently localized using diaminobenzidine tetrahydrochloride (DAB) as a chromogen. As a control for anti-EGF immunoreactivity, EGF peptide (Serotec) was preincubated with anti-EGF antibody and used in place of the EGF antibody alone in the normal staining procedure. Tissues treated in this manner showed no positive staining. Sections were examined by two independent observers blinded to the disease status of the animal.

Statistical analysis. Data are expressed as mean \pm SD unless stated otherwise. Statistical significance of Northern blot analyses, quantification of in situ hybridisation autoradiographs and tissue and plasma EGF peptide were determined by ANOVA for multiple comparisons. Results obtained for serial urinary EGF were analysed by ANOVA for repeated measures. Analyses were performed using the Statview II + Graphics (Abacus Concepts, Berkeley, Calif., USA) package on an Apple Macintosh Centris 650 (Apple Computer Inc, Cupertino, Calif., USA) computer. A p value less than 0.05 was considered statistically significant.

\section{Results}

Rats that had received STZ were all diabetic (Table 1). Diabetes was associated with reduced body mass and increased kidney weight when compared with control animals (Table 1).

Northern analysis. Compared with control animals, kidney EGF mRNA in diabetic rats was increased 3-4 fold on day 1 with further overexpression continuing throughout the study period $(\mathrm{p}<0.001)$ (Figs. $1,2)$. In the diabetic group there was no relationship between EGF expression (mRNA or urinary EGF protein) and either body weight or plasma glucose.

In situ hybridisation and immunohistochemistry In situ hybridisation and immunohistochemistry demonstrated EGF mRNA and protein in the DCT and TAL. No change in the pattern of distribution of either mRNA or protein was found in kidneys from diabetic rats compared with control animals (Figs. 3-6) with no sites of aberrant EGF expression in diabetic rats. Specificity of immunohistochemical staining and in situ hybridisation for EGF was confirmed by the absence of labelling in negative controls (Figs. 7 and 8). Examination by blinded observers did not detect a difference in the relative distribution of EGF protein or mRNA in the DCT compared with TAL in control compared to diabetic animals. Similarly, quantitative autoradiography showed no difference in the cortex:outer medulla ROD between control and diabetic rats $(0.36 \pm 0.01$ vs $0.40 \pm 0.08$, control vs diabetic $)$. 


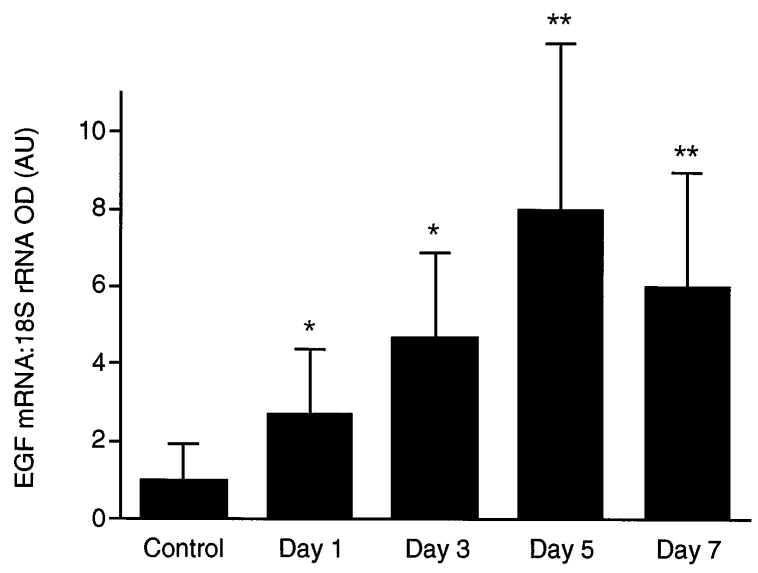

Fig. 2. Quantitation of kidney EGF mRNA in control and diabetic animals. Data are means \pm SD of the ratio of optical density (OD) in arbitrary units (AU) for EGF mRNA to that of $18 \mathrm{~S}$ rRNA. $* p<0.05, * * p<0.01$
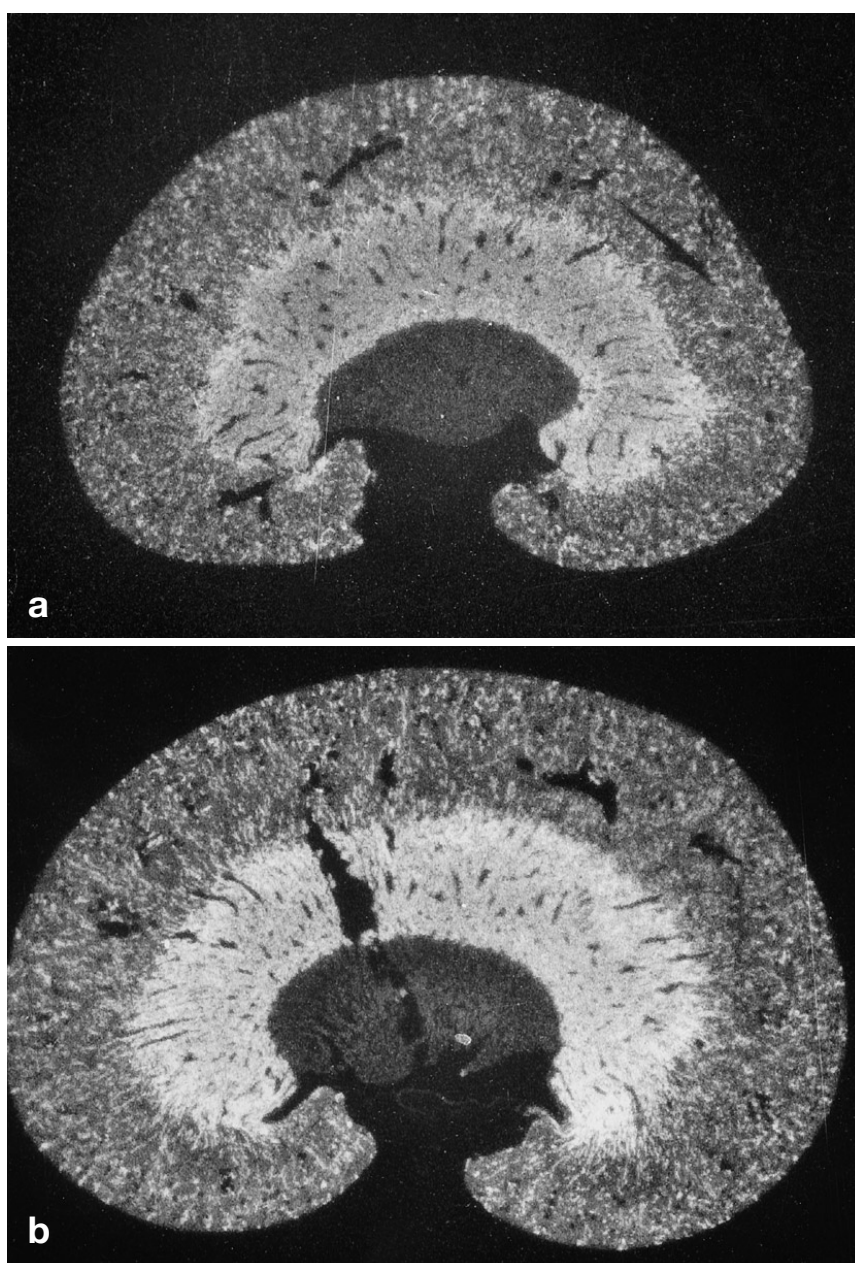

Fig. 3. In situ hybridisation of EGF mRNA in sagittal section of kidney from control (a) and diabetic (b) rat demonstrating hybridisation in the cortex and outer medulla
E GF peptide. Urinary EGF increased on day 1 in diabetic animals, then increased further achieving a plateau level 3 times greater than control animals and baseline levels $(p<0.0001$, Fig. 6$)$. Kidney EGF rose transiently on day 1 and then returned to levels similar to those of control animals (Table 1). There was no significant difference between control and diabetic groups with regard to plasma EGF at any time point (Table 1).

\section{Discussion}

The present study demonstrates that kidney EGF gene expression and peptide excretion increase rapidly following induction of experimental diabetes. The increase in renal EGF mRNA in the diabetic group and absence of a difference in plasma EGF between groups suggest that the increase in urinary EGF excretion in diabetic animals is the result of local production rather than altered plasma clearance. The transient and relatively small increase in kidney EGF in diabetic animals is consistent with the view that EGF is not stored within renal tubular cells for a prolonged period but that following its production the precursor molecule undergoes proteolytic cleavage releasing mature EGF. Furthermore, sites of EGF mRNA were not different in control and diabetic animals suggesting that induction of EGF transcription at aberrant sites within the kidney did not account for EGF overexpression found in the present study.

Diabetes is associated with profound pathophysiological changes in the kidney some of which may be a consequence of the demonstrated increase in EGF. Firstly, experimental diabetes is associated with a rapid increase in kidney size despite a loss of body weight. The factors that mediate this growth are poorly understood. Early increases in renal IGF-I have been demonstrated in experimental diabetes [24, 25]. These findings are consistent with the ability of EGF to increase renal IGF-I production in a dose dependent manner [26] and suggest that these two growth factors acting in concert may be responsible for renal growth in diabetes. In vitro, EGF is a mitogen for tubular epithelial and possibly other renal cell types [27]. For instance, the renal growth that follows unilateral nephrectomy is associated with increased renal EGF $[11,10]$ and the associated tubular cell hyperplasia can be reduced by the administration of anti-EGF antibodies [28]. In acute tubular necrosis following ischaemic injury $[29,30]$ or mercuric chloride toxicity exogenously administered EGF accelerates tubular regeneration and recovery. The factors responsible for increased EGF during early diabetes remain speculative. Proto-oncogenes which modulate gene transcription such as C-fos are increased following glucose exposure in vitro and within $24 \mathrm{~h}$ of the 

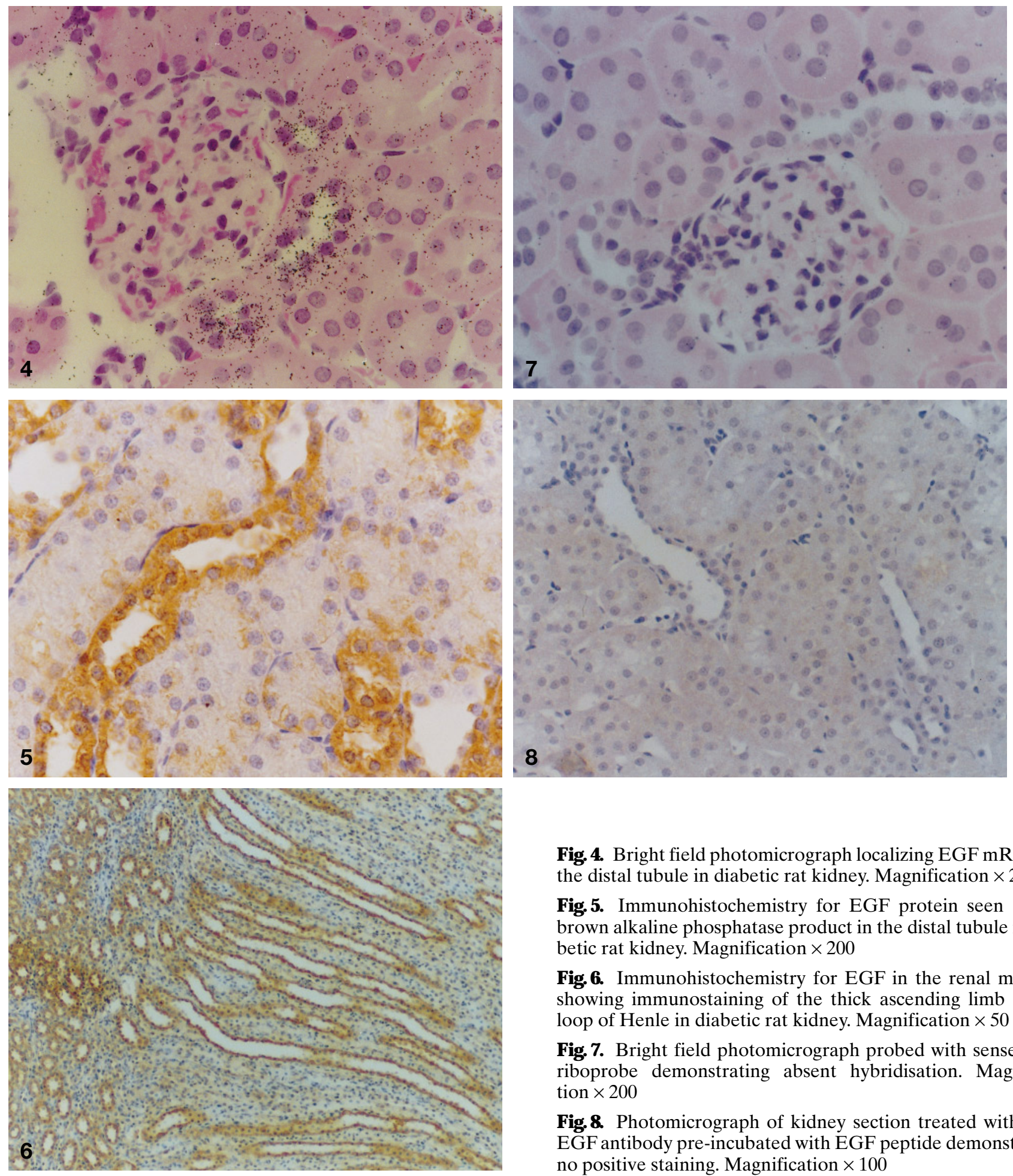

Fig. 4. Bright field photomicrograph localizing EGF mRNA to the distal tubule in diabetic rat kidney. Magnification $\times 200$

Fig. 5. Immunohistochemistry for EGF protein seen as the brown alkaline phosphatase product in the distal tubule in diabetic rat kidney. Magnification $\times 200$

Fig. 6. Immunohistochemistry for EGF in the renal medulla showing immunostaining of the thick ascending limb of the loop of Henle in diabetic rat kidney. Magnification $\times 50$

Fig. 7. Bright field photomicrograph probed with sense EGF riboprobe demonstrating absent hybridisation. Magnification $\times 200$

Fig. 8. Photomicrograph of kidney section treated with antiEGF antibody pre-incubated with EGF peptide demonstrating no positive staining. Magnification $\times 100$

induction of experimental diabetes [33]. These molecules may have a role in the modulation of EGF expression as may glucose-induced protein kinase C stimulation which has been shown to increase EGFreceptor expression in aortic smooth muscle cells [34].

Tissue growth encompasses increased extracellular matrix to accommodate the increased cell numbers. While EGF has been shown to increase collagen

synthesis in kidney cells studied in vitro [35] other growth factors such as transforming growth factor- $\beta$ (TGF- $\beta$ ) which is also increased in early diabetes-related kidney growth [36] are more likely candidates for the early accumulation of extracellular matrix in diabetes [37]. However, the growth factor milieu of the microenvironment within the kidney may be in part responsible for the differing patterns of growth 


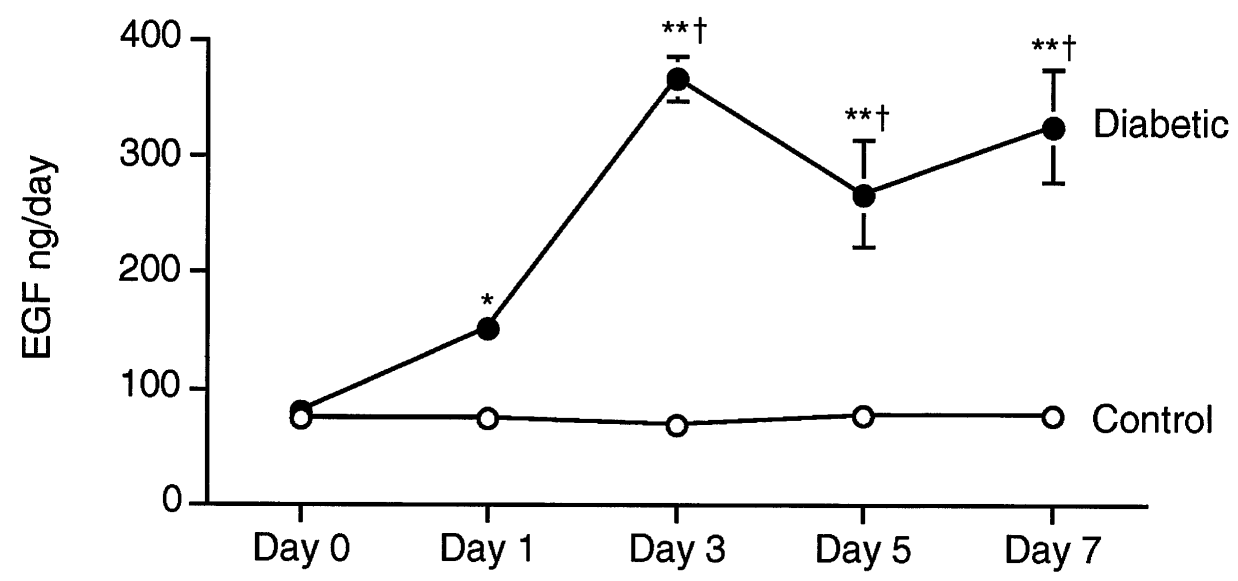

Fig. 9. 9. Urinary excretion of EGF in control $(\bigcirc)$ and diabetic rats $(\bigcirc)$. $* p<0.01$ vs day 0 and control, $* * p<0.001$ vs day 0 and control, $\uparrow p<0.001$ vs day 1

of the tubule compared with the glomerulus. For instance, in the renal tubule which undergoes hyperplasia in diabetes [38] EGF is found abundantly while the generally anti-proliferative cytokine TGF- $\beta$ is not [39]. The converse applies to the glomerulus which undergoes predominantly hypertrophic changes [38]. Although a study of STZ-diabetic rats did find EGF mRNA in sieved glomeruli using Northern analysis [13] no change in gene expression was noted following the induction of experimental diabetes. These findings are not easily understood in the context of in situ studies in the present report and other studies in which EGF mRNA was not found in the glomerulus of the mouse [40] or in humans [41].

Increased kidney mass found at $36 \mathrm{~h}$ following the induction of STZ diabetes continues rapidly for the first week and then slows but continues for up to 6 weeks [3]. Thus the previously reported increase in urinary EGF reported at 2 days of diabetes [12] may have been a consequence of increased kidney size rather than an initiating factor. The present study extends these initial findings by documenting increased EGF mRNA and urinary EGF peptide at $24 \mathrm{~h}$ following STZ injection, prior to a change in kidney weight. In humans, renal enlargement is present at diagnosis in insulin-dependent diabetes and does not increase with diabetes duration. Thus the findings of similar levels of urinary EGF in long-term diabetic and control subjects [42] are consistent with EGF being involved in initial kidney growth and later returning to normal levels when growth ceases, as has been described in compensatory renal enlargement following unilateral nephrectomy [11].

The location of EGF and its receptors within the kidney is not completely understood and may change in pathological states. For instance, in control rats EGF is localised immunohistochemically almost exclusively to the distal tubules and collecting duct whereas following nephrotoxic injury substantial EGF immunoreactivity appears in the proximal tubule $[43,44]$. In contrast to nephrotoxic injury, experimental diabetes was not associated with any alteration in the sites of EGF expression in the present study. With regard to EGF binding to cells, kinetic analysis has revealed the presence of a low affinity non-saturable kidney tubular lumen uptake mechanism in addition to high affinity binding localised to the basolateral portion of the cell [45]. It is hypothesized that with the increased amount of EGF passing through the renal tubules in early diabetes as found in the present study the luminal uptake mechanism may assume a greater importance in determining EGF action. However, EGF is unlikely to be the sole growth factor involved in kidney growth in early diabetes. Increased gene expression of other growth factors such as platelet-derived growth factor and TGF- $\beta$ have been found in the glomerulus in experimental diabetes [13]. Proliferation in cells of the proximal tubule may reflect the actions of still other growth factors such as the recently described heparin-binding EGF-like growth factor which is increased in STZ-diabetes [46] and has been postulated to stimulate mitogenesis in the proximal tubule by acting as a paracrine growth factor through binding to EGF receptors at that site [47].

In conclusion, induction of experimental diabetes is associated with increased EGF as a result of elevated gene transcription from normal sites within the kidney. In the context of the known biological actions of EGF the findings of the present study are consistent with a role for this growth factor in early diabetes-related kidney growth.

A cknowledgements. This work was supported by a grant from the Diabetes Australia Research Trust.

\section{References}

1. Mogensen CE, Andersen MJP (1973) Increased kidney size and glomerular filtration in early juvenile diabetes. Diabetes 22: 706-712 
2. Seyer-Hansen K (1983) Renal hypertrophy in experimental diabetes. Kidney Int 23: 643-646

3. Kleinman KS, Fine LG (1988) Prognostic implications of renal hypertrophy in diabetes mellitus. Diabetes Metab Rev 4: 179-189

4. Inomata S (1993) Renal hypertrophy as a prognostic index for the progression of diabetic renal disease in non-insulin-dependent diabetes mellitus. J Diabet Complications 7: 28-33

5. Seyer-Hansen K (1976) Renal hypertrophy in streptozotocin-diabetic rats. Clin Sci Mol Med 51: 551-555

6. Fisher DA, Salido EC, Barajase L (1989) Epidermal growth factor and the kidney. Ann Rev Physiol 51: 67-80

7. Massagué J (1990) Transforming growth factor- $\alpha$. J Biol Chem 265: 21393-21396

8. Fisher DA, Lakshmanan J (1990) Metabolism and effects of epidermal growth factor and related growth factors in mammals. Endocrinol Rev 11: 418-442

9. Hamm LL, Hering-Smith KS, Vehaskari VM (1993) Epidermal growth factor and the kidney. Semin Nephrol 13: 109-115

10. Miller SB, Rogers SA, Estes CE, Hammerman MR (1992) Increased distal nephron EGF content and altered distribution of peptide in compensatory renal hypertrophy. Am J Physiol 262:F1032-F1038

11. Kanda S, Saha PK, Nomata K et al. (1991) Transient increase in renal epidermal growth factor content after unilateral nephrectomy in the mouse. Acta Endocrinol 124: 188-193

12. Guh JY, Lai YH, Shin SJ, Chuang LY, Tsai JH (1991) Epidermal growth factor in renal hypertrophy in streptozotocin-diabetic rats. Nephron 59: 641-647

13. Nakamura T, Fukui M, Ebihara I et al. (1993) mRNA expression of growth factors in glomeruli from diabetic rats. Diabetes 42: 450-456

14. Schmidt FH (1961) Enzymatic determination of glucose and fructose simultaneously. Klin Wochenschr 39: 1244 1247

15. Chomczynski P, Sacchi N (1987) Single-step method of RNA isolation by acid guanidinium thiocyanate-phenolchloroform extraction. Anal Biochem 162: 156-159

16. Stein-Oakley A, Tzanidis A, Fuller PJ, Jablonski P, Thomson NM (1994) Expression and distribution of epidermal growth factor in acute and chronic renal allograft rejection. Kidney Int 46: 1207-1215

17. Saggi SJ, Safirstein R, Price PM (1992) Cloning and sequencing of rat preproepidermal growth factor cDNA: comparison with mouse and human sequences. DNA Cell Biol 11: 481-487

18. Gilbert RE, McNally PG, Cox A et al. (1995) SPARC gene expression is reduced in early diabetes related kidney growth. Kidney Int 48: 1216-1225

19. Kriz W, Bankir L (1988) A standard nomenclature for structures of the kidney. Kidney Int 33: 1-7

20. Baskin DG, Stahl W (1993) Fundamentals of quantitaive autoradiography by computer densitometry for in situ hybridization with emphasis on ${ }^{33} \mathrm{P}$. J Histochem Cytochem 41: 1767-1773

21. Mendelsohn F, Dunbar M, Allen A et al. (1987) Localization of angioteinsin II receptors in rat and monkey kidney by in vitro autoradiography. Kidney Int [Suppl] 31:S40-S44

22. Wookey PJ, Tikellis C, Du H-C, Qin H-F, Sexton PM, Cooper ME (1996) Amylin binding in rat renal cortex, stimulation of adenylyl cyclase and activation of plasma renin. Am J Physiol 270:F289-F294

23. Jørgensen PE, Hilchey SD, Nexø E, Poulsen SS, Quilley CP (1993) Urinary epidermal growth factor is excreted from the rat isolated perfused kidney in the absence of plasma. J Endocrinol 139: 227-234

24. Flyvbjerg A, Thorlacius-Ussing O, Naerra R, Ingerslev J, Orskov H (1988) Kidney tissue somatomedin C and initial renal growth in diabetic and uninephrectomized rats. Diabetologia 31: 310-314

25. Bach LA, Jerums G (1990) Effect of puberty on initial kidney growth and rise in kidney IGF-I in diabetic rats. Diabetes 39: 557-562

26. Rogers SA, Miller SB, Hammerman MR (1991) Insulinlike growth factor I gene expression in isolated rat renal collecting duct is stimulated by epidermal growth factor. $\mathbf{J}$ Clin Invest 87: 347-351

27. Kanda S, Nomata K, Saha PK et al. (1989) Growth factor regulation of renal cortical tubular cells by epidermal growth factor, insulin-like growth factor I, acidic and basic fibroblast growth factors and transforming growth factor- $\beta$ in serum free culture. Cell Biol Int Rep 13: 687-699

28. Kanda S, Igawa T, Sakai H, Nomata K, Kanetake H, Saito Y (1992) Anti-epidermal growth factor antibody inhibits compensatory renal hyperplasia but not hypertrophy after unilateral nephrectomy in mice. Biochem Biophys Res Comm 187: 1015-1021

29. Norman J, Tsau Y-K, Bacay A et al. (1990) Epidermal growth factor accelerates functional recovery from ischaemic acute tubular necrosis in the rat:role of the epidermal growth factor receptor. Clin Sci 78: 445-450

30. Humes HD, Cieklinski DA, Coimbra TM et al. (1989) Epidermal growth factor enhances renal tubule cell regeneration and repair and accelerates the recovery of renal function in post ischemic acute renal failure. J Clin Invest 84: $1757-1761$

31. Coimbra TM, Cieklinski DA, Humes HD (1990) Epidermal growth factor accelerates renal repair in mercuric chloride nephrotoxicity. Am J Physiol 259:F438-F443

32. Kreisberg JI, Radnik RA, Ayo SH, Garoni J, Saikumar P (1994) High glucose elevates c-fos and c-jun transcripts and proteins in mesangial cell cultures. Kidney Int 46: 105-112

33. Shankland SJ, Scholey JW, Ly H, Thai K (1995) Expression of growth-related protooncogenes during diabetic renal hypertrophy. Kidney Int 47: 782-788

34. Xia P, Feener EP, King GL (1994) Elevated glucose level regulates epidermal growth factor receptor (EGF-R) in aortic smooth muscle cells overexpressing protein kinase C. Diabetes 43: 101 (Abstract)

35. Creely JJ, DiMari SJ, Howe AM, Hyde CP, Haralson MA (1990) Effect of epidermal growth factor on collagen synthesis by an epithelioid cell line derived from normal rat kidney. Am J Pathol 136: 1247-1257

36. Shankland SJ, Scholey JW, Ly H, Thai K (1994) Expression of transforming growth factor- $\beta 1$ during diabetic renal hypertrophy. Kidney Int 46: 430-442

37. Østerby R, Gundersen GHJ (1980) Fast accumulation of basement membrane material and the rate of morphological change in acute experimental glomerular hypertrophy. Diabetologia 18: 493-500

38. Rasch R, Norgaard JOR (1983) Renal enlargement: comparative autoradiographic studies of ${ }^{3} \mathrm{H}$-thymidine uptake in diabetic and uninephrectomised rats. Diabetologia 25: 280-287

39. MacKay K, Kondiah P, Danielpour D, Austin III HA, Brown PD (1990) Expression of transforming growth factor- $\beta 1$ and $\beta 2$ in rat glomeruli. Kidney Int 38: 1095-1100

40. Salido EC, Yen PH, Shapiro LJ, Fisher DA, Barajas L (1989) In situ hybridisation of prepro-epidermal growth factor mRNA in the mouse kidney. Am J Physiol 256:F632-F638 
41. Gesualdo L, Di Paolo S, Calabró A et al. (1996) Expression of epidermal growth factor and its receptor in normal and diseased human kidney: an immunohistochemical and in situ hybridization study. Kidney Int 49: 656-665

42. Dagogo-Jack S, Marshall SM, Kendall-Taylor P, Alberti KGMM (1989) Urinary excretion of human epidermal growth factor in the various stages of diabetic nephropathy. Clin Endocrinol 31: 167-173

43. Nonclercq D, Toubeau G, Lambricht P, Heuson-Stiennon JH, Laurent G (1991) Redistribution of epidermal growth factor immunoreactivity in renal tissue after nephrotoxin induced tubular injury. Nephron 57: 210-215

44. Toubeau G, Nonclercq D, Zanen J et al. (1991) Distribution of epidermal growth factor in the kidneys of rats exposed to amikacin. Kidney Int 40: 691-699
45. Kim DC, Hanano M, Sawada Y, Iga T, Sugiyama Y (1988) Kinetic analysis of clearance of epidermal growth factor in isolated perfused rat kidney. Am J Physiol 261:F988-F997

46. Lee YJ, Shin SJ, Lin SR, Tan MS, Tsai JH (1995) Increased expression of heparin binding epidermal growth factor-like growth factor mRNA in the kidney of streptozotocin-induced diabetic rats. Biochem Biophys Res Comm 207: 216-222

47. Homma T, Sakai M, Cheng HF, Yasusa T, Coffey RJ, Harris RC (1995) Induction of heparin-binding epidermal growth factor-like growth factor mRNA in rat kidney after acute injury. J Clin Invest 96: 1018-1025 